\title{
PHYTOTOXIC EFFECT OF DISTILLERY EFFLUENTS ON GERMINATION, SEEDLING LENGTH, SEEDLING VIGOUR AND FIELD EMERGENCE IN WHEAT (Triticum aestivium L.)
}

\section{Ashish Lambat', Shanti Patil' ${ }^{2}$, Suresh Dhapke², Sanjiv Charjan², Rajesh Gadewar ${ }^{1}$}

${ }^{1}$ Dr. P.D.K.V's, College of Agriculture, Nagpur, M. S, India.

${ }^{2}$ Sevadal Mahila Mahavidyalaya and Research Academy, Nagpur.

Corresponding Author Email : rajeshgadewar29@gmail.com

\section{ABSTRACT:}

Laboratory and field work has been carried out to study the effect of distillery effluent (coming out of biomethanation plant of distillery) on seed germinability, seedling vigour and field emergence of Black gram. In the present investigation the germination paper were soaked in effluent at concentration ranging 1 o 100 percent and for control in distilled water. The black gram seed germination percentage in control was $90 \%$. In $100 \%$ effluent treatment, the germination percentage was zero. From this experiment, it was observed that $1 \%$ and $5 \%$ effluent treatment showed increase in germination percentage, seedling vigour and field emergence over control. The germination percentage, seedling vigour and field emergence in Black gram significantly decreased with increase in concentration of effluent above $5 \%$.

Key words: Germination percentage, seedling vigour, field emergence percentage, effluent, wheat

\section{INTRODUCTION:}

Effluent is resulting liquid flow from the waste water treatment system of sugar factory or distilleries. For the production of 1 liter of alcohol, nearly 10 to 14 liters of effluent are discharged as wastewater. Every distillery unit generating 5 to 10 lakh liters of raw effluent every day. The effluent is disposed off in to water bodies and soil as well as water well which has been causing major pollution problem. Recycling effluent through irrigating plant is a must for future generations to avoid ecological disasters on earth, because the plant roots and associated bacteria remove polluting chemicals from wastewater and photosynthesizing plant leaves help to remove atmosphere gases which are 
increasing in the atmosphere causing the earth temperature increase (Wolverton et. al. 1989).

According to World Bank untreated distillery contains suspended soil (10 to $60 \mathrm{mg} / \mathrm{L}), \mathrm{BOD}(1000$ to $1500 \mathrm{mg} / \mathrm{L})$ and $(800$ to $3000 \mathrm{mg} / \mathrm{L})$. Sugar factory effluent and distillery effluent constitutes number of physico-chemical elements such as suspended and dissolved solid with high amount of biological oxygen demand, COD chloride, sulphide, calcium, magnesium, nitrate as well as some trace amount of heavy metals such as zinc, copper and lead. The presence of these chemicals in large quantities in the effluent which is used for irrigation and not only affect seed germination and plant growth but also deteriorate the physico-chemical characters of soil. The present work deals with the study of effect of distillery effluents on germinability, seedling vigour and field emergence in wheat.

\section{MATERIALS AND METHODS:}

The experiment was conducted with the distillery effluent coming out of the distillery after treatment. The physico-chemical properties of effluent were analyzed following the standard procedures (Anon.1965). The aerobic and anaerobic population of various groups of microorganisms in the effluent was enumerated using the standard serial dilutions plating technique (Waksman and Fred, 1992). Seeds of wheat were treated with 0.05 percent of mercuric chloride to disinfect it and then washed several times with sterilized distilled water. The evaluation of germination on the basis of normal seedlings by blotter germination paper method (Anonymous, 1985). The effluents were studied for their effect on germination, length of radical, length of plumule, seedling vigour and field emergence of wheat seeds. In the present investigation the blotter germination paper were soaked in following concentrations ranging 1 to 100 percent for control in distilled water. In each treatments three replication each of 100 seeds were maintained. 
For soaking seeds in effluent six treatment with control as a seventh treatment.

T1-1\% effluent $/ 1 \mathrm{ml}$. made up to $100 \mathrm{ml}$. with distilled water.

T2- $5 \%$ effluent $/ 5 \mathrm{ml}$. made up to $100 \mathrm{ml}$. with distilled water.

T3-10\% effluent/ $10 \mathrm{ml}$. made up to $100 \mathrm{ml}$. with distilled water.

T4-15\% effluent/ $15 \mathrm{ml}$. made up to $100 \mathrm{ml}$. with distilled water.

T5-20\% effluent/ $20 \mathrm{ml}$. made up to $100 \mathrm{ml}$. with distilled water.

T6-100\% effluent

T7-Control- blotter germination paper soaked in distilled water.

For field emergence test, sterilized neutral soil was taken in tea cups and one seed sown in each tea cup. For irrigation with this effluent the above seven treatment were fixed and irrigated daily. The observation on germination, seedling length, seedling vigour index and field emergence were taken on $7^{\text {th }}$ day from the start of experiment. The seedling vigour index were calculated according to Abdul-Baki and Anderson (1973). The data was statistically analysed with the help of Panse and Sukhatme (1967)

\section{RESULT AND DISCUSSION:}

The values of different physical characteristics in distillery effluent are given in Table-1

Table -1: The physical characteristics of the effluent.

\begin{tabular}{|c|c|c|c|c|c|c|c|}
\hline $\begin{array}{l}\text { Name of } \\
\text { effluent }\end{array}$ & Colour & Odour & Tempoc & Turbidity & $\begin{array}{l}\text { Total } \\
\text { solids } \\
\text { (CPPM) }\end{array}$ & $\begin{array}{l}\text { Suspended } \\
\text { solids } \\
\text { (PPM) }\end{array}$ & $\begin{array}{l}\text { Dissolved } \\
\text { solids } \\
\text { (PPM) }\end{array}$ \\
\hline $\begin{array}{l}\text { Distillery } \\
\text { effluent }\end{array}$ & $\begin{array}{l}\text { Dark } \\
\text { brown }\end{array}$ & $\begin{array}{l}\text { Decaying } \\
\text { molasses }\end{array}$ & $\begin{array}{ll}29 & \text { to } \\
580 \mathrm{C}\end{array}$ & $\begin{array}{l}\text { Highly } \\
\text { Turbid }\end{array}$ & $\begin{array}{l}1612 \text { to } \\
1906 \\
\text { PPM }\end{array}$ & $\begin{array}{l}531 \text { to } \\
719 \\
\text { PPM }\end{array}$ & $\begin{array}{l}1201 \text { to } \\
1340 \mathrm{PPM}\end{array}$ \\
\hline
\end{tabular}


The values of different chemical characteristics estimated in distillery effluent are given $\mathrm{m}$ (PPM) in Table-2

\begin{tabular}{|l|l|l|}
\hline Sr. No. & Chemical Characters & Estimation \\
\hline 1 & PH & 7.0 to 6.0 \\
\hline 2 & Electrical conductivity (mhos $/ \mathrm{cm})$ & 30 to 40 \\
\hline 3 & Total nitrogen (PPM) & 1512 to 1850 \\
\hline 4 & Amoniacal nitrogen & 1179 to 1189 \\
\hline 5 & Total phosphate(PPM) & 407 to 451 \\
\hline 6 & Total potassium (PPM) & 9600 to 10612 \\
\hline 7 & Calcium (PPM) & 1091 to 1104 \\
\hline 8 & Magnesium (PPM) & 2199 to 2301 \\
\hline 9 & Sodium & 530 to 549 \\
\hline 10 & Chlorides (PPM) & 9680 to 10700 \\
\hline 11 & Sulphates (PPM) & 2200 to 3600 \\
\hline 12 & BOD (PPM) & 5332 to 5914 \\
\hline 13 & COD (PPM) & 33000 to 41100 \\
\hline 14 & Dissolved oxygen (PPM) & 0.006 to 0.009 \\
\hline
\end{tabular}

Table-3: The biological characteristics of effluent.

\begin{tabular}{|l|l|l|}
\hline Sr. No. & Biological Characters & Estimation \\
\hline 1 & Bacteria $\left(\mathrm{X} 10^{5} / \mathrm{ml}\right)$ & 13 to 25 \\
\hline 2 & Fungi $\left(\mathrm{X} 10^{3} / \mathrm{ml}\right)$ & 37 to 59 \\
\hline 3 & Actinomycetes $\left(\mathrm{X} 10^{4} / \mathrm{ml}\right)$ & 8 to 11 \\
\hline 4 & Yeast $\left(\mathrm{X} 10^{2} / \mathrm{ml}\right)$ & 23 to 31 \\
\hline
\end{tabular}

The values of different physical, chemical and biological characters estimated in distillery effluents are given in Table 1, Table 2 and Table 3 respectively. 
Table-4: The effect of distillery effluent to germination, seedling length, seedling vigour and field emergence.

\begin{tabular}{|l|l|l|l|l|l|l|}
\hline $\begin{array}{l}\text { Sr. } \\
\text { No. }\end{array}$ & Treatment & $\begin{array}{l}\text { Germination } \\
\text { (\%) }\end{array}$ & $\begin{array}{l}\text { Plumule } \\
\text { length } \\
\text { (cm) }\end{array}$ & $\begin{array}{l}\text { Radical } \\
\text { length } \\
\text { (cm) }\end{array}$ & $\begin{array}{l}\text { Seedling } \\
\text { vigour } \\
\text { index } \\
\text { (SVI) }\end{array}$ & $\begin{array}{l}\text { Field } \\
\text { emergence } \\
\text { (\%) }\end{array}$ \\
\hline 1 & $\begin{array}{l}\text { T1- } 1 \% \\
\text { effluent }\end{array}$ & 98 & 13.7 & 17.3 & 3038 & 90 \\
\hline 2 & $\begin{array}{l}\text { T2-5\% } \\
\text { effluent }\end{array}$ & 95 & 12.1 & 15.9 & 2660 & 85 \\
\hline 3 & $\begin{array}{l}\text { T3-10\% } \\
\text { effluent }\end{array}$ & 84 & 8.6 & 11.4 & 1680 & 72 \\
\hline 4 & $\begin{array}{l}\text { T4-15\% } \\
\text { effluent }\end{array}$ & 74 & 7.2 & 9.8 & 1184 & 60 \\
\hline 5 & $\begin{array}{l}\text { T5-20\% } \\
\text { effluent }\end{array}$ & 60 & 5.7 & 6.3 & 720 & 45 \\
\hline 6 & $\begin{array}{l}\text { T6-100\% } \\
\text { effluent }\end{array}$ & 00 & 00 & 00 & 00 & 00 \\
\hline 7 & T7- Control & 88 & 10.3 & 13.7 & 2112 & 78 \\
\hline & S.E.D. & 5.01 & ----- & ----- & ----- & 3.99 \\
\hline & C.D. & 15.06 & ----- & ----- & ---- & 12.00 \\
\hline
\end{tabular}

Data from Table 4 revealed that the control (T7) showed a seed germination of $88 \%$ while in other treatments the range was 60 to $98 \%$ the minimum being in T5, T4 and T3 $(20 \%, 15 \%$ and $10 \%$ effluent). T6 (100\% effluent) recorded zero percent germination. There was maximum germination percentage in $\mathrm{T} 1$ and $\mathrm{T} 2$ ( $1 \%$ and $5 \%$ effluent) treatment over the $\mathrm{T} 7$ (control). From the experiment it was observed that $1 \%$ and $5 \%$ effluent treatment showed increase in germination percentage over control. Sahai et al. (1983) studied the effects of the various concentrations of the distillery effluent of the germinability of seeds, seedling growth, pigment content and biomass of Phaseolus radiatus L. They reported that the distillery effluent was found beneficial up to $15 \%$ for the overall growth of the plant. The germination percentage in wheat significantly decreased with increase in concentration of effluent above $5 \%$. This may be due to phytotoxic effect of effluent on black 
gram seeds. Sahai et al. (1983), Kannan (2002), Pande (2008), Gaikwad et al. (2010) and Charjan et al. (2012) reported that the germination percentage decreased as the effluent concentration increased.

The length of seedling and seedling vigour index also found maximum in $\mathrm{T} 1$ and $\mathrm{T} 2$ (1\% and 5\% effluent) treatment as compared to other treatments. The seedling length and seedling vigour index was significantly decreased with increase in concentration of effluent above $5 \%$. Similar observation also reported by Sahai et al. (1983), Kannan (2002), Gaikwad (2010) and Charjan et. al. (2012). In the seedling length, radical growth was found more adversely affected than the plumule growth. This is conformity with the observations of Sahai (1983) and Charjan et al. (2012) in Phaseolus radiatus and mungbean respectively.

Similarly the superiority of $\mathrm{T} 1$ and $\mathrm{T} 2$ (1\% and 5\% effluent) treatment in case of field emergence percentage were observed as compared to other treatments. The field emergence treatment of wheat significantly decreased with increase in concentration of effluent above $5 \%$. This might be due to inhibitory effect of effluent on wheat seeds in an outcome of its high salt and toxic metals content. Similar result also observed by Lauchli and luttge (2000) and Charjan et al. (2012).

The present investigation suggests that $1 \%$ and $5 \%$ effluent treatment showed increase in germination percentage, seedling length, seedling vigour index and field emergence over control. The above parameters significantly decreased with increase in concentration of effluent above $5 \%$ as it showed phytotoxic effect. 


\section{REFERENCES:}

Anonymous (1965). Standard methods for the examination of water and waste water. American public health association, A.W.P.C.F., Broadway, New York.

Abdul - Baki and J. D. Anderson (1973). Vigour determination in soybean seed by multiple criteria. Crop Sci. 13: $630-633$.

Charjan, S., Lambat, A., Gadewar, R., Charde, P., Bhandari, P. and Kamdi, R. (2012). Effect of distillery effluent on germinability, seedling vigour and field emergence in Mungbean. Journal of Science Information. Special Issue3:141-144.

Gaikwad, S. S., K. A. Ahad Najam, D. D. Wanule and C. S. Bhowate (2010). Phytotoxic effect of sugar factory effluent and distillery effluent on turkishbean. Bionano Frontier.3(2): 256 - 258.

Kannan, J. (2001). Effect of distillery effluents on crop plants. Ad.Plant Sci. 14(1):127-132.

Lauchli, A and Luttge, U. (2000). Salinity- Environments-Plants Molecules. Kluwer Academic Publisher, Dordrecht, the Netherlands.

Pandey, A. K., Dutta, S. and Sharma, K.C. (2002). Impact of marble slurry on sub surface water- A case study of Kishangarh. Dist-Ajmer. Envirn. Pollut. Technol. 1: 5 to 11 .

Panse, V. G. and P. V. Sukhatme (1967). Statistical methods for Agricultural workers. ICAR Publication, New Delhi.

Sahai, R.S., Jabeen and Saxena (1983). Effect of distillery effluent on seed germination, seedling growth, pigment content and biomass of phaseolus radiatus L. Indian J. Ecol. 14:21-25 .

Waksman,S.A. and Fred, E. B. (1992). A tentative outline of the plate method for determining the number of micro-organisms in soil. Soil Sci. 14:27-28. Wolverton (1989). Treatment of industrial waste water. Biocycle. $30: 48-50$. 